\title{
BREEDING SEASON, FECUNDITY, LENGTH-WEIGHT RELATIONSHIP AND CONDITION FACTOR OF OREOCHROMIS NILOTICUS L. (PISCES: CICHLIDAE) IN LAKE TANA, ETHIOPIA
}

\author{
Zenebe Tadesce \\ Department of Biology, Bahir Dar Teachers' College \\ P0 Box 79, Bahir Dar, Ethiopia
}

\begin{abstract}
The breading season, fecundity, length-weight relationship and condition factor of Oreochromis niloticus from Lake Tana, Ethiopia, were studied from monthly samples collected using a bottom trawl between March, 1992 and March, 1993. In Lake Tana Oreochromis niloticus spawns throughout the year, with a high activity between April and August peaking in June and July. The peak spawning coincided with the onset of the rainy season. There was a curvilinear relationship between fecundity and total length (TL) $(\log F=-0.01+$ 2.01LogrL, $r=0.86, p<0.001$ ) and a linear relationship between fecundity and body weight $(W)(F=234.65+1.51 \mathrm{TW}, \mathrm{r}=0.84, \mathrm{p}<0.001)$ and gonad weight $(\mathrm{GW})(\mathrm{F}=394.55+29.1 \mathrm{GW}, \mathrm{r}=0.67, \mathrm{p}<0.001)$. The length-weight relationship was less than a cube, LogTw $=-1.373+2.742 \mathrm{LogTL}, \mathrm{n}=680, \mathrm{r}=0.97$, $p<0.001$ indicating allometric growth of the firh. The length-weight regression coefficients for both males (2.748) and females (2.747) were almost the same. A significant seasonal fluctuation (ANOVA, $p<0.001$ ) was observed in the condition of the fish. The relatively low values during April to August may be due to the high energy cost of spawning.
\end{abstract}

Key words/phrases: Allometric growth, breeding season, Fulton's condition factor, fecundity, Oreochromis niloticus

\section{INTRODUCTION}

Tilapia (Cichlidae) are widely distributed in tropical and sub-tropical waters of Africa, South America and Asia (Fryer and lles, 1972). The tilapia, Oreochromis niloticus, occurs in almost all the lakes and streams of Ethiopia (Shibru Tedla, 1973), and accounts for about $60 \%$ of the annual commercial fishery (LFDP, 1995). 
Reproductive biology of $O$. niloticus from Ethiopian Rift Valley Lakes was studied by Zenebe Tadesse (1988) and Demeke Admassu (1994; 1997). Food and feeding habits were studied by Getachew Teferra (1987), Getachew Teferra and Fernando (1989), Eyualem Abebe and Getachew Teferra (1992), Getachew Teferra (1993) and Zenebe Tadesse and Getachew Teferra (1997) and age and growth was studied by Demeke Admassu (1989) and Yosef Tekle-Giorgis (1990).

O. niloticus is a maternal mouth brooding species that breeds continuously throughout the year in the Rift Valley Lakes, Ziway (Zenebe Tadesse, 1988) and Awassa (Demeke Admassu, 1997). There are peak breeding months where spawning is intensive and these months are associated with changes in environmental factors such as rainfall, temperature, and photoperiod (Zenebe Tadesse, 1988; Demeke Admassu, 1997).

Most studies of $O$. niloticus have been limited to the Rift Valley Lakes Ziway, Awassa and Chamo. By contrast, very little is known about this important fish of the non-rift valley lake, Lake Tana. Earlier reports about the fish fauna and limnology of this lake are very old and incomplete (Talling and Rzoska, 1967; Rzoska, 1976). However, recent studies have described 14 distinct morphotypes of large barbs (Barbus spp.) from Lake Tana based on differences in general morphology, distribution and feeding habit (Mina et al., 1993; Nagelkerke et al., 1995a). Mina et al. (1993) suggested that these morphological differences are evident after the fish attained sexual maturity. In contrast, Nagelkerke et al. (1995b) reported the possibility of distinguishing between most of the morphotypes at an earlier stage ( $<12 \mathrm{~cm}$ fork length). Eventhough, their taxonomic status is still uncertain.

Oreochromis niloticus is the preferred fish for consumption by the local population and accounts for about $37 \%$ of the commercial fishery of Lake Tana (LFDP, 1995). Proper management and rational utilization of this resource requires basic biological knowledge on the fish such as feeding, reproduction and growth. However, such basic data are not available for $O$. niloticus from Lake Tana. Thus, studies on the basic biology and ecology of this fish are essential. 
The main objectives of this study were to assess fecundity rate and breeding season of the fish and to estimate the length-weight relationship and condition factor of $O$. niloticus in Lake Tana.

\section{DESCRIPTION OF THE STUDY AREA}

Lake Tana $\left(12^{\circ} \mathrm{N}\right.$, and $\left.37^{\circ} 20^{\prime} \mathrm{E}\right)$ is located at an altitude of $1829 \mathrm{~m}$ in the north-western part of Ethiopia. It is the largest lake in the country and covers an area of $3150 \mathrm{~km}^{2}$. It has a maximum depth of $14 \mathrm{~m}$ and a mean depth of 8.9 m (Rzoska, 1976). The lake was probably formed during the late Pliocene or early Pleistocene as a result of volcanic action which uplifted the surrounding mountains (Rzoska, 1976). The diel temperature varies from 23 to $30^{\circ} \mathrm{C}$ during the day time and falls below $10^{\circ} \mathrm{C}$ in the night (Fig. la). The annual rain fall may reach up to $2000 \mathrm{~mm}$ : the main rainy season extends from June to October peaking during June to August (Rzoska, 1976).

Among the 60 rivers that flow into the lake, the little Abbay, the Rib and the Gumera rivers are the largest. Lake Tana is the source of the River Abbay (the Blue Nile) which outflows at the south-eastern corner of the lake. The shores are partly rocky but especially at the mouth of affluent rivers there is an extensive macrophyte vegetation including Cyperus, Scirpus, Paspalidium, Phragmites, Ceratophylum and Nymphea. The vegetation provides spawning and nursery grounds for $O$. niloticus.

The bicarbonate plus carbonate, calcium, magnesium and sodium ions dominate the water chemistry of the lake. In contrast, nitrate-nitrogen is very low reaching below detection level (Talling and Rzoska, 1967). The major genera of phytoplankton in the lake include Microcystis, Anabaena, Melosira, Surirella, Staurastrum and Pediastrum (Talling, 1976). The known genera of zooplankton are Mesocyclops, Thermocyclop, Diaphanosoma, Bosmina, Daphnia, Keratella, Brachionus and others (Tesfaye Wudneh, pers. comm.). In addition to the 14 barbus-morphotypes (Nagelkerke et al., 1995b) the fish fauna of Lake Tana is composed of $O$. niloticus, Clarias gariepinus, Varicorhinus beso, Gara quadrimaculata and $G$. dembeensis. The most important fish species which account for about $98 \%$ the fishery are $O$. niloticus, Barbus spp. and $C$. gariepinus (LFDP, 1995). 


\section{MATERIALS AND METHODS}

Monthly samples from two sites were collected between March 1992 and March 1993 with a bottom trawl of a code end mesh size of $40 \mathrm{~mm}$. Trawling was done for about 30 minutes during each sampling occasion. All fish collected were mixed and a random sub-sample of 30 to 60 fish were taken for analysis. Total length (TL) and total weight (TW) of each fish were measured to the nearest $0.1 \mathrm{~cm}$ and $0.1 \mathrm{~g}$, respectively. Sex of each fish was determined by examination of gonads and the weight of gonads was recorded to the nearest 0.1g. Gonado-somatic index (GSI), gonad weight as a percentage of total body weight, was calculated for each fish. Maturity of the gonads was determined according to Siddiqui (1977) and Babiker and Ibrahim (1979). Fecundity was determined by counting all ripe eggs in ovaries that were preserved in Gilson's fluid (Synder, 1983). Length-weight relationship was constructed using least squares regression fitted to $\log$ transformed length and weight data, i.e., LogTw $=\log a+b \log \mathrm{T}$, where $\mathrm{a}$ and $\mathrm{b}$ are constants fitted by least squares regression.

Fulton's condition factor was calculated (Le Cren, 1951; Bagenal and Tesch, 1978). Fulton's condition factor $=(\mathrm{TW} / \mathrm{TL} 3) \times 100$ where, $\mathrm{TW}$ is in grams and $\mathrm{TL}$ is in centimetres.

A chi-square test was employed to determine if the sex-ratio varied between months and with fish size. Fluctuations in Fulton's condition factor as well as in GSI values were statistically (ANOVA) tested if they varied in samples between months (Sokal and Rohlf, 1981).

\section{RESULTS}

A total of 6800 . niloticus individuals were examined in 13 sampling occasions. Males were more numerous than females (chi-square, $p<0.05$ ) in the total catch as well as in samples from April, May and June (Table 1). There was also a preponderance of males in length-groups that were larger than $27.0 \mathrm{~cm}$ TL (Table 2). 
Table 1. The number of males, females and sex-ratio in monthly samples of $\boldsymbol{O}$. niloticus caught from Lake Tana. The last column shows chi-square values. *, Significant $(p<0.05)$.

\begin{tabular}{lcccc}
\hline Month & Males & Females & $\begin{array}{c}\text { Sex ratio } \\
\text { (male: female) }\end{array}$ & Chi-square \\
\hline Mar. '92 & 22 & 17 & $1: 0.77$ & 0.64 \\
Apr. & 44 & 15 & $1: 0.34$ & $14.25 *$ \\
May & 36 & 21 & $1: 0.58$ & 3.95 \\
Jun. & 42 & 17 & $1: 0.41$ & $10.59 *$ \\
Jul. & 25 & 22 & $1: 0.88$ & 0.19 \\
Aug. & 23 & 26 & $1: 1.13$ & 0.18 \\
Sep. & 17 & 16 & $1: 0.94$ & 0.03 \\
Oct. & 31 & 23 & $1: 0.74$ & 0.19 \\
Nov. & 25 & 22 & $1: 0.88$ & 0.19 \\
Dec. & 25 & 36 & $1: 1.44$ & 1.98 \\
Jan. '93 & 28 & 26 & $1: 0.93$ & 0.07 \\
Feb. & 32 & 29 & $1: 0.91$ & 0.15 \\
Mar. & 33 & 28 & $1: 0.85$ & 0.41 \\
\hline Total & 383 & 297 & $1: 0.78$ & $10.88 *$ \\
\hline
\end{tabular}

The gonado-somatic indices varied significantly (ANOVA, $\mathrm{p}<0.001$ ) between months. GSI values of females ranged from $0.43 \pm 0.03$ to $2.45 \pm 0.25$ (mean $\pm \mathrm{SE}$ ) whereas those of males ranged from $0.09 \pm 0.01$ to $0.99 \pm 0.08$. High aSI values were evident between April and August for both sexes. The peak occurred in June for females and in June and July for males (Fig. lb). The values were generally low during the rest of the sampling period except for the slight increase that was observed between January and March, 1993. This increase was more pronounced in males than females (Fig. lb). However, sex by month interaction was insignificant (ANOVA, $p=0.068$ ) suggesting that the pattern of seasonal fluctuation on GSI was similar in both sexes.

Oreochromis niloticus with ripe gonads were caught throughout the year, however, their frequency in the catch varied seasonally (Fig. 1c). Ripe females were more frequent during April to August than during the rest of the year. However, the frequency of ripe males slightly increased between January and March in 1993 (Fig. 1c). The results from seasonal fluctuation in GSI and the 
frequency of ripe fish suggest that $O$. niloticus in Lake Tana breeds intensively between April and August, but some individuals may breed throughout the year.

Table 2. The number of males, females and sex-ratio in samples of $O$. nilloticus caught from Lake Tana. Samples were grouped in $2.0 \mathrm{~cm}$ length classes. The last column shows chi-square values. *, Significant $(p<0.05)$.

\begin{tabular}{ccccc}
\hline Length (cm) & Males & Females & $\begin{array}{c}\text { Sex-ratio } \\
\text { (male: female) }\end{array}$ & Chi-square \\
\hline 13 & 3 & 1 & $1: 0.33$ & 1.00 \\
15 & 7 & 4 & $1: 0.57$ & 0.82 \\
17 & 16 & 7 & $1: 0.44$ & 3.52 \\
19 & 33 & 47 & $1: 1.42$ & 2.45 \\
21 & 44 & 61 & $1: 1.39$ & 2.75 \\
23 & 73 & 52 & $1: 0.68$ & 3.53 \\
25 & 78 & 62 & $1: 0.79$ & 1.83 \\
27 & 53 & 44 & $1: 0.83$ & 0.84 \\
29 & 38 & 12 & $1: 0.32$ & $13.52^{*}$ \\
31 & 22 & 5 & $1: 0.23$ & $10.70^{*}$ \\
$>32$ & 16 & 2 & $1: 0.13$ & $10.89 *$ \\
\hline Total & 383 & 297 & $1: 0.78$ & $10.88^{*}$ \\
\hline
\end{tabular}

Fecundity of $O$. niloticus in Lake Tana ranged from 495 to 1243 eggs for femaies whose length was between 21 and $31.5 \mathrm{~cm}$ and weight was between 190 and $570 \mathrm{~g}$. The mean fecundity was 730 eggs (standard deviation $=168$, $\mathrm{n}=45$ ). Fecundity was curvilinearly related with $\mathrm{TL}$ (Fig. 2a), and linearly related with TW (Fig. 2b) as well as with gonad weight (Fig. 2c).

There was a significant $(p<0.001, n=680$ ) curvilinear relationship between $\mathrm{TL}$ and $\mathrm{TW}$ of $O$. niloticus in Lake Tana. The regression equation which was fitted for fish between 12 and $34.8 \mathrm{~cm} \mathrm{TL}$ and 40 and $743 \mathrm{~g}$ TW was as follows:

Males: $\operatorname{LogTw}=-1.383+2.748 \operatorname{LogTL}(r=0.974, p<0.001, n=383)$.

Females: LogTw $=-1.377+2.747 \operatorname{LogTL}(r=0.965, p<0.001, n=297)$. Males and females: $\log \mathrm{TW}=-1.373+2.742 \log \mathrm{TL}(\mathrm{r}=0.971, \mathrm{p}<0.001$, $n=680$ ). 

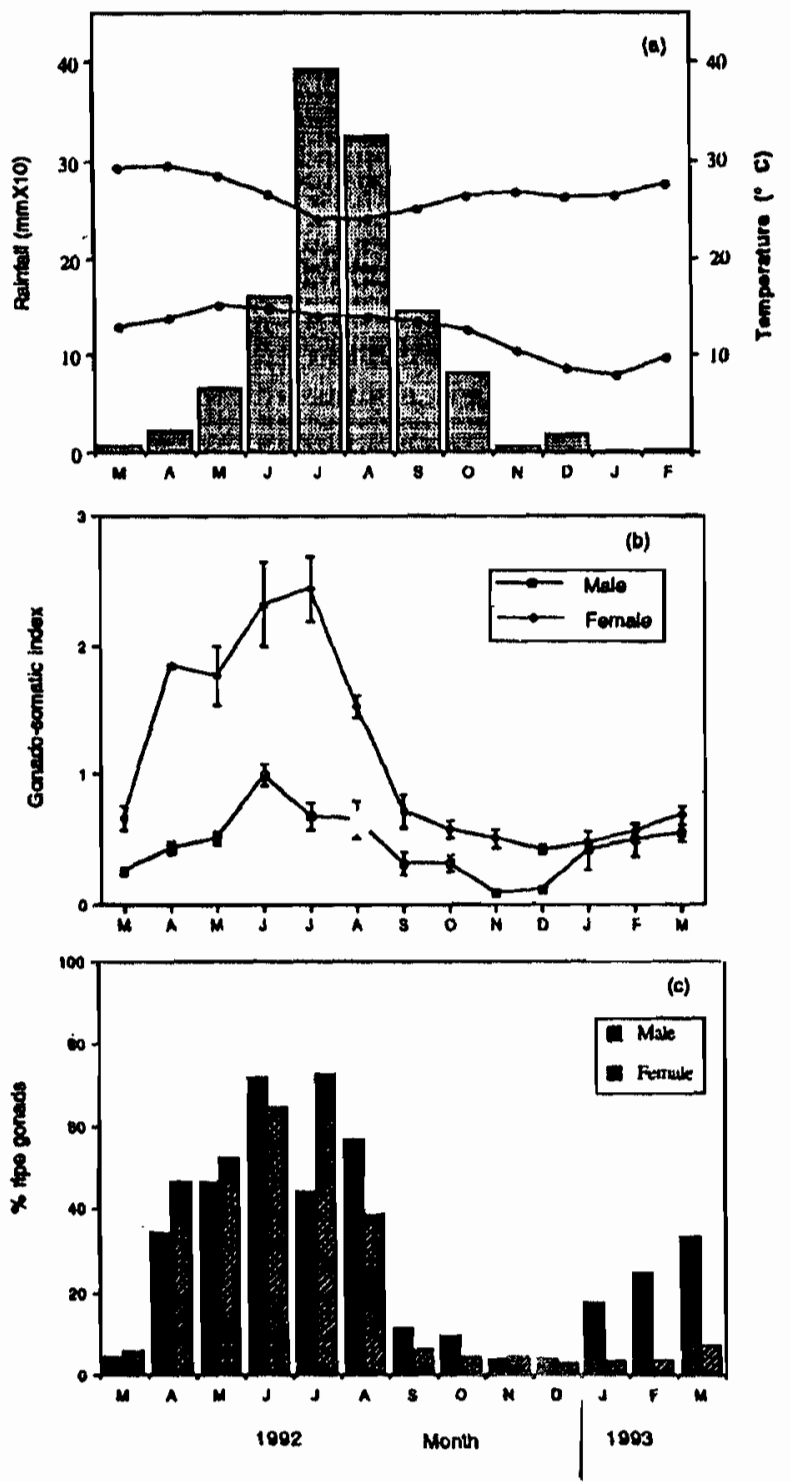

Fig. 1. Monthly mean total rainfall (bar) and air temperature (line) around Lake Tana between 1979 and 1988 (a), seasonal variation in gonadosomatic index (b) and frequency of ripe gonads (c) of Oreochromis niloticus. Vertical bars indicate standard error of the mean. 

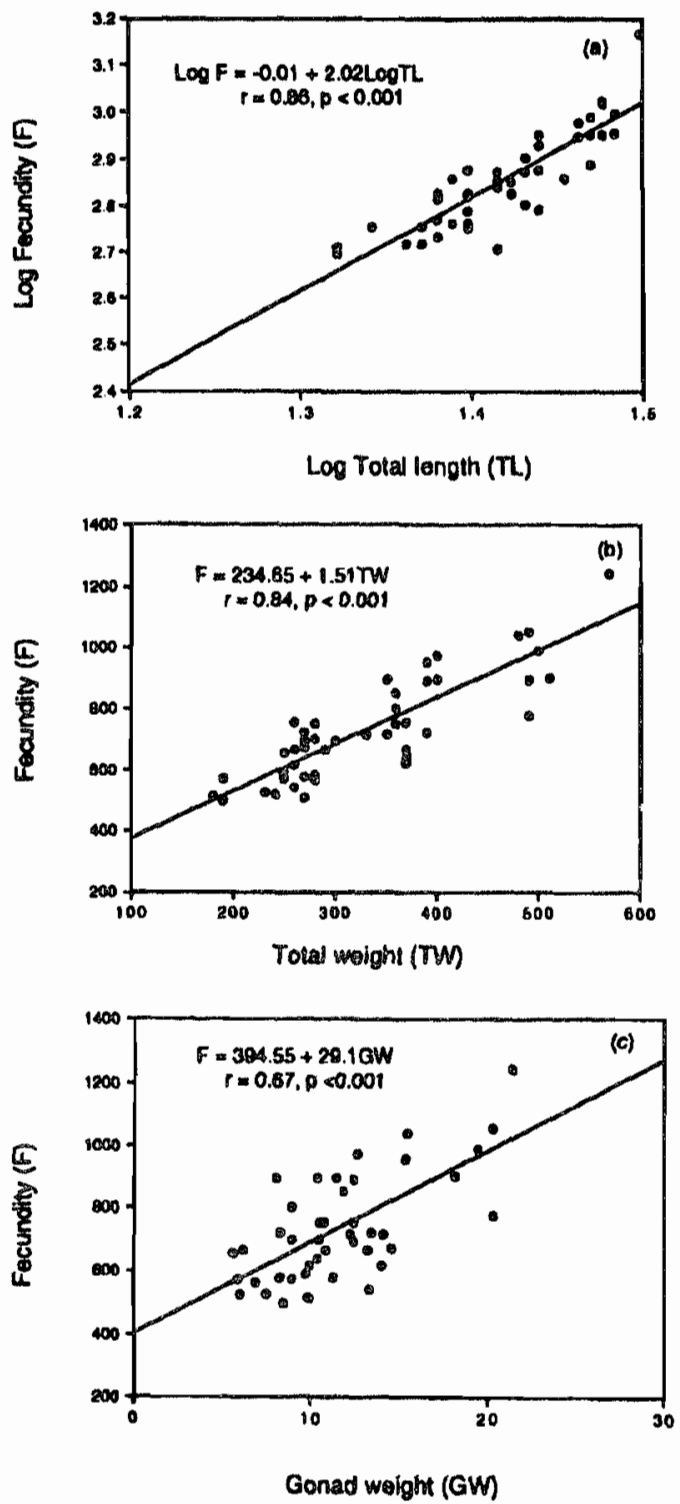

Fig. 2. Relationship between fecundity and total length (a), fecundity and total weight (b) and fecundity and gonad weight (c), $n=45$. 
Fulton's condition factor of the fish ranged from 1.47 to 2.29 for females and from 1.44 to 2.37 for males. The values were found to be significantly different between months (ANOVA, $\mathrm{p}<0.001$ ). Thus, the values were relatively lower between May and August (Fig. 3) which seem to coincide with the peak breeding season of the fish (cf. Figs $1 \mathrm{~b}$ and $1 \mathrm{c}$ ).

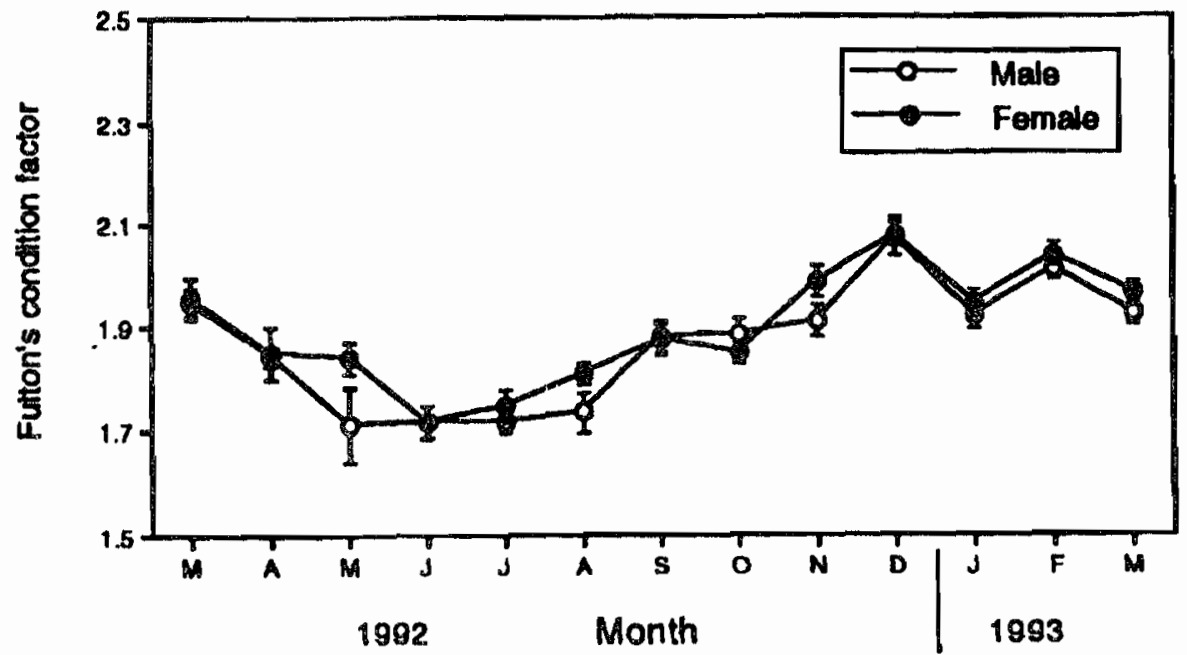

Fig. 3. Seasonal variation in the Fulton's condition factor of Oreochromis niloticus. Vertical bars represent standard error of the mean.

\section{DISCUSSION}

This study demonstrates that males predominated in the catch that was taken during the peak spawning period of the fish and this could be one of the reasons why males were more numerous than females in the total catch as well as in size groups above $27 \mathrm{~cm}$ TL (Tables 1 and 2, Figs $1 \mathrm{~b}$ and 1c). The preponderance of males over females in the catch taken during the peak breeding season may be explained by the interactive effects of the reproductive behaviour of the fish and the sampling gear. During the spawning season, male tilapia build their spawning nests at the bottom and guard them against intruders 
(Lowe-McConnell, 1958; 1959). In addition, the males are polygamous and thus stay at their breeding nests to court several females (Lowe-McConell, 1958; 1959). The females, on the other hand, move to their brooding sites in the vegetation zones up in the water column immediately after fertilization (Lowe-McConell, 1958; 1959). Thus, the males stay longer at the bottom of the water making them more vulnerable than the females to be caught by the gear used in this study (bottom trawl). This may also be the reason why males dominated over the females particularly in sexually mature fish (>27 cm TL). In contrast, gill nets set at the water surface are likely to catch more females than males. This was reported by Demeke Admassu (1994) who found a preponderance of females over males in $O$. niloticus from Lake Awassa in gill net catches taken during the peak fish breeding seasons. He also attributed his results to the breeding behaviour of the fish and to the type of gear he used. Sex-ratio in favour of males has been reported to the related mouth brooding species $T$. leucostica in Lake Naivasha (Siddiqui, 1977). Lowe-McConnell (1959) has also suggested that in tilapia a preponderance of males in catches may indicate peak breeding season.

Oreochromis niloticus in Lake Tana breeds intensively during April to August (Figs $1 \mathrm{~b}$ and 1c). However, some breeding activity may take place at other times of the year as well. Environmental factors such as temperature and photoperiod influence gonadal development in tilapia (Balarin and Hatton, 1979), but this is only possible in the temperate regions where there is a marked seasonal fluctuation in these factors. In the tropics however, seasonal fluctuations in temperature and photoperiod are generally very low, and this might be favourable for some tropical fish to spawn at any time of the year (LoweMcConnell, 1982). Similarly, this may be the reason why breeding $O$. niloticus in Lake Tana were present throughout the year. Other species of Tilapia were also found to spawn year round (Siddiqui, 1977; 1979). Rainfall is another environmental factor associated with spawning in tropical fish in general and in tilapia in particular (Zenebe Tadesse, 1988; Demeke Admassu, 1997). The rainy season at Lake Tana was coincident with the peak spawning activity of $O$. niloticus (Figs la,b and c). Evidently, rainfall increases production (phytoplankton, zooplankton) of waters because of the resulting nutrient load by run off (Elizabeth Kebede $e t$ al., 1994). This in turn insures the availability of sufficient food for better growth and survival of the off-springs of tilapia fish 
(Jalabert and Zohar, 1982). In addition, the quality of the available food may also be improved after the rainy season. A study that was conducted concurrently with the present (Getachew Teferra pers. comm.), for instance, showed that the food ingested by $O$. niloticus in Lake Tana after the rainy season contained high levels of organic matter and protein and low levels of hydrolysis resistant organic matter. In addition, rainfall increases water level which in turn provides suitable spawning grounds for adults and feeding and nursery grounds for the young (Jalabert and Zohar, 1982). Since the macrophyte vegetation of Lake Tana grows extensively following the rainy season, the juvenile $O$. niloticus would be provided with suitable shelter and minimize the risk of predation by piscivores. Thus, rainfall appears to be an important environmental cue associated with the intensive spawning activity of $O$. niloticus in Lake Tana between April and August (Fig. 1a).

Similar studies (Zenebe Tadesse, 1988; Tudorancea et al., 1988; Demeke Admassu, in press) have shown that the fish in the rift valley lakes of Ethiopia spawn throughout the year. However, breeding was intensive between December and March in Lake Ziway (Zenebe Tadesse, 1988) and during January to March and July to September in Lake Awassa (Tudorancea $e t$ al., 1988; Demeke Admassu, 1997). Stewart (1988) also reported that the species in Lake Turkana breeds continuously but peak breeding occurs during March to July. Peak spawning activity of $O$. niloticus in the above studies has been attributed to rainfall and to factors associated with it, and agree well with the present study.

Fecundity of $O$. niloticus in Lake Tana was related nearly to the square $(\mathrm{b}=$ 2.01) of fish length (Fig. 2a). This is low when compared with substrate spawners where fecundity is related to the cube of their length (Simpson, 1951; Lowe-McConnell, 1959). The low fecundity of $O$. niloticus could be due to the mouth brooding behaviour of the fish as the number of spawn will be limited by the size of the buccal cavity (Lowe-McConnell, 1955; Babiker and lbrahim, 1979). Moreover, Lowe-McConnell (1955) stated that mouth-brooding tilapia tend to produce large but few eggs due to better parental care they provide for their offspring. A comparably low fecundity has been reported for the same species from Lakes Ziway $(b=2.16)$ Zenebe Tadesse (1988), Lake Awassa $(b=2.39)$, Demeke Admassu (1994) and from the White Nile $(b=2.02)$ Babiker 
and Ibrahim (1979) supporting the result obtained in this study. Siddiqui (1977) also reported a low value $(b=2.17)$ of fecundity for the related mouth brooding T. leucostica. Fecundity was linearly related to total weight (Fig. 2b) as well as to gonad weight (Fig. 2c). Similar relationships were also reported by other workers for the same species (Demeke Admassu, 1994), and the related T. leucostica (Siddiqui, 1977). The relatively weak correlation $(r=0.67)$ between fecundity and gonad weight might be due to differences in the size of ripe oocytes. Large ovaries were found to contain fewer oocytes (Welcomme, 1967), and this might account for the poor correlation observed between fecundity and ovary weight.

The curvilinear relationship between weight and length of $O$. niloticus in Lake Tana was less than a cube $(b=2.74)$ for both sexes. This coefficient is expected to be near three since growth in weight represents an increase in three dimensions whereas length measurements are taken in one dimension (Bwanthondi and Pratap, 1981). However, the apparently low value of the coefficient might be because of shortage of food (phytoplankton) available for the fish in the lake. In a similar study, a value close to cube was obtained from the Rift valley lakes, Ziway $(b=3.03$ (Zenebe Tadesse, 1988)) and Awassa $(b=3.01$ (Demeke Admassu, 1990)) for the same species. These two lakes contain a relatively high algal biomass (Awassa $18.3 \mu \mathrm{g}(1)^{-1}$; Ziway, $154.2 \mu \mathrm{g}(1)^{-1}$ (Elizabeth Kebede et al., 1994)) when compared with Lake Tana $\left(3.7 \mu g(1)^{-1}\right.$ (Talling, 1976)). Thus, although food is seldom limiting under natural conditions, the relatively low algal biomass in Lake Tana, might be less than sufficient for optimum growth of the fish.

The condition factor of the fish varied significantly (ANOVA, $\mathrm{p}<0.001$ ) between months (Fig. 3). Low condition factor of $O$. niloticus in Lake Tana is coincident with the peak spawning season of the fish. Spawning drains metabolic resources for the production of sperm and eggs (Fryer and Iles, 1972). In addition, in species such as $O$. niloticus females brood their young in the buccal cavity and the males are actively engaged in building and guarding nests and in fertilizing several females (Lowe-McConell, 1958, 1959). Thus, feeding intensity of $O$. niloticus may be reduced if the fish is actively engaged in breeding activities. This could be the reason why the condition factor of $O$. niloticus in Lake Tana was relatively low during the fish peak breeding season. Similar conclusions 
were made for the same species from Lakes Ziway (Zenebe Tadesse, 1988) and Lake Awassa (Demeke Admassu, 1994). Stewart (1988) also correlated the decreased condition of $\boldsymbol{O}$. niloticus during the peak breeding period in Lake Turkana with increased reproductive activity of the fish which causes erratic feeding and depletion of bodily reserves.

Studies on the breeding season, fecundity and related parameters have practical significance for $O$. niloticus fishery. The legal minimum mesh size (stretched) of the gill net for the tilapia fishery of Lake Tana and of most other lakes in Ethiopia is $100 \mathrm{~mm}$. This gill net at Lake Awassa for instance, is reported to catch a considerable number of spawning fish during their breeding period (Demeke Admassu, 1994). In addition, the length of 50\% maturity of $O$. niloticus in Lake Awassa, i.e., $18.8 \mathrm{~cm}$ for females and $19.8 \mathrm{~cm}$ for males (Demeke Admassu, 1994), is similar to the fish in Lake Tana, i.e., $18.1 \mathrm{~cm}$ for females and $20.7 \mathrm{~cm}$ for males (Tesfaye Wudneh pers. comm.). Thus, it is highly probable that the gill net being used at Lake Tana may remove a significant number of spawning fish during their peak breeding season. Hence, it is essential to investigate the effect of commercial gill netting on the $O$. niloticus stock of Lake Tana so that appropriate management actions can be taken to sustain the yield.

\section{ACKNOWLEDGEMENTS}

I am very grateful to my colleagues, Eyualem Abebe, Tesfaye Abera, Solomon Libsu, (the late, Tesfaye Assefa), Getnet Bekele, Worku Negash and Enanu Abesha for their help during sample collection. I would also like to express my gratitude to Ato Tesfaye Wudineh (MOA) for allowing me to use his boat and the trawl net for sampling. I also thank Demeke Admassu for his comment on the draft of the manuscript. This study was financially and materially supported by the Research and Publications Office of the Addis Ababa University and the Swedish Agency for Research Cooperation with Developing Countries (SAREC). 


\section{REFERENCES}

1. Babiker, M.M and Ibrahim, M. (1979). Studies on the biology of reproduction in the cichlid Tilapia nilotica (L.); gonadal maturation and fecundity. J. Fish Biol. 14:437-448.

2. Bagenal, T.B. and Tesch, F.W. (1978). Age and growth. In: Methods for Assessment of Fish Production in Freshwaters, pp. 101-136, (Bagenal, T.B., ed.). Oxford: IBP Handbook No. 3, Blackwell Scientific Publications, Oxford, England.

3. Balarin. J.D. and Hatton, J. (1979). Tilapia: A guide to Their Biology and Culture in Africa. University of Stirling, Scotland, $142 \mathrm{pp}$.

4. Bwanthondi, P.J. atid Pratap, H.B. (1981). The length-weight relationships of fishes of Kunduchi Creek, Dar-es-Salaam, Tanzania. J. mar. biol. Ass. India. 23:161-163.

5. Demeke Admassu (1989). A study on the age and growth of adult Oreochromis niloticus (Pisces: Cichlidae) in Lake Awassa, Ethiopia. Unpubl. MSc thesis, School of Graduate Studies, Addis Ababa University, 90 pp.

6. Demeke Admassu (1990). Some morphometric relationships and the condition factor of Oreochromis niloticus (Pisces: Cichlidae) in Lake Awassa, Ethiopia. SINET: Ethiop. J. Sci. 13(2):83-96.

7. Demeke Admassu (1994). Maturity, fecundity, brood-size and sex-ratio of Tilapia (Oreochromis niloticus L.) in Lake Awassa. SINET: Ethiop. J. Sci. 17(1):53-69.

8. Demeke Admassu (1997). The breeding season of tilapia, Oreochromis niloticus L. in Lake Awassa (Ethiopian Rift Valley). Hydrobiologia. (In Press).

9. Elizabeth Kebede, Zinabu G/Mariam and Ahlgren, I. (1994). The Ethiopian Rift Valley lakes: chemical characteristics of a salinity-alkalinity series. Hydrobiologia. 289:1-12.

10. Eyualem Abebe and Getachew Teferra (1992). Seasonal changes in the nutritional status of Oreochromis niloticus L. (Pisces: Cichlidae) in Lake Ziway, Ethiopia. Arch. Hydrobiol. 124:109-122.

11. Fryer, G. and Iles, T.D. (1972). The Cichlid Fishes of The Great Lakes of Africa. Their Biology and Evolution. Oliver and Boyd, Edinburgh, 641 pp. 
12. Getachew Teferra (1987). Food, nutrition and digestive efficiency in Oreochromis niloticus L. (Pisces: Cichlidae) in Lake Awassa, Ethiopia. PhD dissertation, University of Waterloo, Canada, 109 pp.

13. Getachew Teferra (1993). The composition and nutritional status of the diet of Oreochromis niloticus in Lake Chamo, Ethiopia. Journal of fish Biology. 42:865-874.

14. Getachew Teferra and Fernando, C.H. (1989). The food habits of an herbivorous fish (Oreochromis niloticus Linn.) in Lake Awassa. Hydrobiologia 174:195-200.

15. Jalabert, B. and Zohar, Y. (1982). Reproductive, physiology of Cichlid fishes, with particular reference to Tilapia and Sarotherodon. In: The Biology and Culture of Tilapias, pp. 129-140, (Pullin, R.S.V. and Lowe-McConnell, R. H., eds). Proceedings of the International Conference Manila, Philippines, ICLARM.

16. Le Cren, E.D. (1951). The length-weight relationship and seasonal cycle in gonadal weight and condition in the perch (Percafluviatilis). J. Anim. Ecol. 20:201-219.

17. Lowe-McConnell, R.H. (1955). The fecundity of Tilapia species. E. Afr. Agric. J. 21:45-52.

18. Lowe-McConnell, R.H. (1958). Observations on the biology of Tilapia nilotica L. in East African waters. Rev. Zool. Bot. Afr. 57:129 170.

19. Lowe-McConnell, R.H. (1959). Breeding behaviour patterns and ecological differences between Tilapia species and their significance for evolution within the genus Tilapia (Pisces: Cichlidae). Proc. Zool. Soc. Lond. 132:1-30.

20. Lowe-McConell, R.H. (1982). Tilapias in fish communities. In: The Biology and Culture of Tilapias, pp. 43-83, (Pullin, R.S.V. and Lowe-McConell, R.H., eds). ICLARM, Conference Proceedings 7. Manila, Philippines.

21. LFDP (Lake Fisheries Development Project) (1995). Fisheries Statistical Bulletin No. 2 LFDP Working Papers No. 19 Ministry of Agriculture, Addis Ababa. $30 \mathrm{pp}$.

22. Mina, M.V., Mironovsky, A.N. and Dgebuaze, Y.Y. (1993). Allometrie te divergence entre les barbeaux du Lac Tana (Ethiopia). Calliers d'Ethologie 13:219-222. 
23. Nagelkerke, L.A.J., Mina, M.V., Tesfaye Wudneh, Sibbing, F.A. and Osse, J.W.M. (1995a). In Lake Tana, a unique fish fauna needs protection. BioScience 45:772-775.

24. Nagelkerke, L.A.J., Sibbing, F.A. and Oșse, J.W.M. (1995b). Morphological divergence during growth in the large barbs (Barbus spp.) of Lake Tana, Ethiopia. Netherlands Journal of Zoology 45:431-454.

25. Rzoska, J. (ed.) (1976). The Nile, Biology of an Ancient River. Dr. W. Junk b.v., Publishers, The Hague, 417 pp.

26. Shibru Tedla. (1973). Fresh Water Fishes of Ethiopia. HSIU, Addis Ababa, 101 pp.

27. Siddiqui, A.Q. (1977). Reproductive biology, length-weight relationship and relative condition of Tilapia leucostica (Trewavas) in Lake Naivasha, Kenya. J. Fish Biol. 10:251-260.

28. Siddiqui, A.Q. (1979). Reproductive biology of Tilapia zilli (Garvais) in Lake Naivasha, Kenya. Environ. Biol. Fishes: 4:257-262.

29. Simpson, A.C. (1951). The fecundity of the plaice. Fish Invest. Lond. 17:1-29.

30. Sokal, R.R. and Rohlf, F.J. (1981). Biometry. W.H. Freeman and Company, San Fransisco.

31. Stewart, K.M. (1988). Changes in condition and maturation of the Oreochromis niloticus L. population of Ferguson's Gulf, Lake Turkana, Kenya. J. Fish Biol. 33:181-188.

32. Synder, D.A. (1983). Fish eggs and larvae. In: Fisheries Techniques, pp. 103-131, (Nielson, L.A. and Johnson, D.L., eds), Bethesda, Maryland.

33. Talling, J.F. (1976). Phytoplankton: Composition, development and productivity. In: The Nile, Biology of an Ancient River, pp. 385-402, (Rzoska, J., ed). Dr. W. Junk b.v., Publishers, The Hague.

34. Talling, J.F. and Rzoska, J. (1967). The development of plankton in relation to hydrologic regime in the Blue Nile. J. EcoL 55:637-662.

35. Tudorancea, C., Femando, C.H. and Paggi, J.C. (1988). Food and feeding ecology of Oreochromis niloticus juveniles in Isalse Awassa (Ethiopia). Arch. Hydro. Biol. Suppl. 79:267-289.

36. Welcomme, R.H. (1967). The relationship between fecundity and fertility in the mouth brooding cichlid fish Tilapia leucostica. J. Zool Lond 151:453-468. 
37. Yosef Tekle-Giorgis (1990). Age determination and growth estimation of immature Oreochromis niloticus L. (Pisces: Cichlidae) in Lake Awassa, Ethiopia. Unpubl. MSc thesis, University of Waterloo, Canada, 137 pp.

38. Zenebe Tadesse (1988). Studies on some aspects of the biology of Oreochromis niloticus L. (Pisces: Cichlidae) in Lake Ziway, Ethiopia. MSc thesis, School of Graduate Studies, Addis Ababa University, $78 \mathrm{pp}$.

39. Zenebe Tadesse and Getachew Teferra (1997). Diel feeding rhythm and assimilation efficiency of Oreochromis niloticus (Pisces: Cichlidae) in Lake Ziway, Ethiopia. Verb. Intermat. Verhein. Limnol. (In press). 